\title{
6.2 Поняття переговорів у контексті альтернативного розгляду спорів у цивільних справах
}

Відповідно до Конституції Україна є демократичною правовою державою. Демократизація суспільства і його основних інститутів передбачає, що в певних випадках воно здатне самостійно вирішувати окремі види конфліктів, що виникають в процесі суспільних відносин. Сучасне законодавство і правозастосовна практика здатні надати цілий ряд альтернативних процедур захисту прав і законних інтересів учасників правовідносин, між якими виник правовий конфлікт. При цьому способи цього захисту можуть бути реалізовані в різних комбінаціях. Це дозволяє вирішувати виникаючі конфлікти набагато ефективніше, не витрачаючи зайвих тимчасових і матеріальних ресурсів.

В основі потреби в переговорах (negotiations) як самостійному вигляді альтернативного вирішення спорів - об'єктивна необхідність спільного погодженого вирішення питань, що представляють інтерес для учасників суспільних відносин.

Значення переговорів у всіх сферах життєдіяльності суспільства постійно зростає[184]. Як універсальний засіб спілкування, унікальний інструмент для вирішення спорів переговори забезпечують згоду, розвиток всебічного співробітництва і соціального партнерства, знімають напругу між сторонами, що знаходяться в стані конфлікту, впорядковують суспільні відносини і навіть у багатьох ситуаціях «дозволяють усунути небезпеку, попередити вчинення тяжких злочинів, уникнути застосування насильства». У цьому полягає соціальна і моральна цінність переговорів.

При інших альтернативних способах вирішення спорів, які $\epsilon$ не переговорними, а змагальними (арбітраж, третейський розгляд), значення переговорів менш виражено. Однак в літературі існує точка зору, в рамках якої навіть судовий процес розглядається як процес переговорів[185].

Конструкція алгоритму (послідовності) застосування способів вирішення юридичного конфлікту повинна містити переговори як один з перших способів 
досягнення згоди сторін. У разі неефективності застосування несудового дозволу юридичного конфлікту сторони або третя сторона вдаються до судочинства найпоширенішому способу вирішення юридичних конфліктів.

Переваги переговорів перед іншими альтернативними способами вирішення спорів можуть бути визначені в наступному: в їх процесі відбувається безпосередня взаємодія сторін; суб'єкти конфлікту мають можливість максимально контролювати різні аспекти своєї взаємодії, в тому числі самостійно встановлювати тимчасові рамки і межі обговорення, впливати на процес переговорів i ïx результат, визначати рамки угоди; переговори дозволяють суб'єктам конфлікту виробити угоду, що задовольняє кожну зі сторін i дозволяє уникнути тривалого судового розгляду, яке може закінчитися програшем однієї з них; специфіка взаємодії суб'єктів конфлікту на переговорах дозволяє зберегти конфіденційність[186].

Як зазначає М. Бове, в результаті переговорів, які він відносить до самоврядним способам врегулювання цивільно-правових спорів, сторони перетворюють правове протиріччя в протиріччя економічне, дозволяючи свій конфлікт на підставі конкретної норми, укладаючи угоду на підставі попередньої оцінки своїх економічних інтересів. Іншими словами, законодавець надає в розпорядження сторін переговорний інструмент, визначаючи можливі умови його використання, і таким інструментом $є$ цивільний кодекс, зокрема, загальна і особлива частини зобов'язального права. Користуючись свободою договору, сторони можуть на власний розсуд, погодивши свої волі, шляхом взаємних поступок щодо початкових позицій домовитися про вибір того чи іншого варіанту врегулювання конфлікту своїх економічних інтересів в встановлених законом рамках, уклавши ту чи іншу угоду. Рамки визначаються імперативними нормами, які задають умови визнання угоди недійсною. На думку М. Бове, якщо в результаті переговорів укладено угоду, то в такому рішенні конфлікту немає перемогла і сторони, що програла, оскільки це рішення не було прийнято суддею за боку. Звісно ж, проте, що це так, лише якщо обидві сторони діяли сумлінно 
під час переговорів і укладену за результатами переговорів підсумкову угоду не є для однієї зі сторін кабальної угодою[187].

Переговори є переважним методом приватного замовлення. В результаті виникають безліч прийомів ведення переговорів, які охоплюють різноманітні соціальні відносини. У своєму широкому розумінні, переговори - це процес спілкування, що передбачає досягнення згоди чи взаємодії для вирішення психологічного протистояння. Переговори стосуються політичних угод, комерційних операцій, переговорів про звільнення заручників, формування державних норм і правил, вирішення суперечливих проблем сім'ї та шлюбу, врегулювання громадських та екологічних проблем, i тому подібних. Відразу стає очевидним, що переговори $€$ надзвичайно гнучким та адаптованим процесом, який можна контекстуалізувати в різних соціальних ситуаціях.

Переговори завжди були пов’язані з адвокатами та правовою системою. Але ніколи до того переговори, що застосовуються в юридичній практиці, не були визначені як юридичні переговори - метод переговорів, який функціонує в рамках правового середовища відповідно до власних унікальних стандартів, цінностей та структури. Причина полягає в тому, що юридичні переговори мають місце одночасно з появою та розвитком системи ADR[188].

ADR надав основу, в якій діють різні значення та орієнтири, що могли збігатись i перехресно стосуватися одне одного щодо теорії та практики переговорів. Переговори є продуктом цього процесу. Через вплив ADR, переговори, як це відбулося в юридичній практиці, були переоцінені не лише 3 юридичної точки зору перспективи, але також на основі міждисциплінарних досліджень. Теоретики юридичних переговорів зверталися до соціальних, антропологічних, психологічних та соціологічних джерел, щоб зрозуміти процес переговорів, як це практикується в його правовому середовищі.

Уявлення про переговори закріплюється у всіх його аспектах та культурах, воно не є невизначеною та випадковою подією, яка використовується як спеціальна основа, але натомість має чіткі процесуальні характеристики. Отже, переговори $\epsilon$ структурованим процесом, який можна використовувати i 
раціонально ним керувати, оскільки він прогресує через низку заздалегідь визначених стадій, хоча і не відповідно до жорстких моделей. Через наголос на процесуальному характері переговорів їх можливо проаналізувати не тільки як процес, а й як юридичні моделі прийняття рішень.

Айзенберг[189] дослідив нормативні питання, що виникають в результаті аналізу розбіжностей між законодавством та рішенням, 3 одного боку, та переговори як неформальний процес прийняття рішень, з іншого боку. На цій підставі, це так можна розрізнити нормотворчі та трансакційні переговори як розширення законодавчої функції та ведення переговорів, як неформальна аналогія офіційного прийняття рішень. Розмежування є принциповим, оскільки воно контекстуалізує правові переговори, що стосуються або створення законних прав, або вирішення суперечок щодо законних прав. Переговори щодо прийняття прав стосуються майбутньої поведінки, поки переговори про суперечки стосуються суперечок, що виникли в результаті минулих подій.

Робота Айзенберга також порушує важливе питання про характер переговорів у контексті системи ADR. Різниця між переговорами щодо нормотворчості та переговорів про суперечки створюють нормативну основу для контекстуалізації двох форм переговорів. Переговори, як основний процес АРС, стосуються переговорів щодо суперечок. Як вказує їх назва, АРС зосереджене на вирішенні суперечок. Ні в якому разі значення переговорів щодо нормотворчості не є заниженим. Обидві форми переговорів є однаково важливими. Однак, як основний альтернативний процес вирішення спорів, переговори слід тлумачити як вирішення суперечок, незалежно від того, чи $є$ їх зміст законним чи неправовим. Тому конкретне значення визначає переговори як основний процес APC.

Поява системи ADR також призвела до критичної оцінки традиційної структури та стратегії юридичних переговорів. Звичайний конкурентний підхід до юридичних переговорів характеризується стандартною роботою[190] розробки методів принципових переговорів[191] та понять інтегративних переговорів[192]. Ці інноваційні підходи до переговорів представляють 
тенденцію, яка відходить від лінійної структури розподілу, характерної для юридичних переговорів у поєднанні з конкурентною стратегією.

Відповідь видно з юридичної літератури, що пішла далі. Кооперативна стратегія Уільямса набула видатного значення[193], підтверджуючи, що стратегія відрізняється від конкурентної, може застосовуватися в рамках змагальної структури юридичних переговорів. Так само, було застосовано інтегративну стратегію на основі моделі вирішення проблем розроблену i впроваджену Менкель-Медоу[194]. 3 різних точок зору, Ловенталь[195] та Гіфорд[196] забезпечують раціональні підстави для вибору стратегії щодо правових переговорів.

У роботах Мнукіна та Корнхаузера[197] мало спільного 3 теорією переговорів, але одна ідея, яку вони висловили, зробила їх роботу відомою. Переговори, що стосуються юридичного спору, відбуваються «в тіні закону», створюючи тим самим переговорний фонд для учасників спору. «Тінь закону» звужує значення переговорів як основного процесу АРС щоразу, коли застосовується в правовому середовищі. Окрім того, вона розуміється як форма переговорів про суперечки, особливий тип переговорів, який можна охарактеризувати як «юридичні переговори» та є продуктом концепції «тіні закону». Ця коротка фраза інкапсулює саму суть переговорів, що відбуваються на тлі юридичних процесів. Юридичні переговори передбачають результат у вигляді винесеного рішення, тим самим запроваджуючи прецедентне, матеріальне право, докази, а також властиві затримки у судовому процесі, його невизначений результат та його непомірні трансакційні витрати, як фактори, що безпосередньо впливають на суть переговорів.

Поняттю юридичних переговорів дали цікаве визначення Кріцер[198] i Галантер[199]. Працюючи з припущенням, що більшість юридичних суперечок врегульовані переговорами, ці автори зазначають, що переконлива присутність судів представляє альтернативу рішення, якщо переговори не проваляться. Ця ідея провокує думку про мету та функцію переговорів як основного вирішення процесуальних суперечок в системі ADR та вказує шлях для подальших 
досліджень щодо взаємозв'язку між юридичними переговорами та судовим рішенням.

Вчення цих авторів, полягає у тому, що переговори - це не випадкова соціальна сфера, подія або нечіткий спосіб спілкування. Переговори мають форму мистецтва та наукову форму. У цій формі можна виділити певні процесуальні етапи, розмежувати певні форми переговорів, визнати їх потенціал як метод вирішення проблеми та проаналізувати хід їх проведення шляхом відбору різних стратегій. Через свою популярність цього методу вирішення спорів, підвищену увагу було зосереджено на ролі та функції процесу переговорів, як вони застосовуються в правовому контексті. Насправді переговори про трудові відносини чи будь-яке інше контекстне застосування можуть бути обрані як не юридичні переговори. У кожному випадку цей спеціалізований контекст певної форми переговорів, який пов'язаний 3 теоретичною моделлю переговорів. Все це дає нам можливість дослідити безперервність між переговорами як неформальним процесом із юридичними переговорами. 